\title{
Effects of nutritional conditions on growth and biochemical composition of Tetraselmis sp.
}

\author{
Mouna Dammak', Bilel Hadrich', Ramzi Miladi', Mohamed Barkallah', Faiez Hentati ${ }^{1}$, Ridha Hachicha', \\ Céline Laroche ${ }^{2,3}$, Philippe Michaud ${ }^{2,3}$, Imen Fendri $^{4}$ and Slim Abdelkafi ${ }^{*}$
}

\begin{abstract}
Background: This study aimed to maximize biomass concentration, biomass productivity and biochemical composition of the marine microalga Tetraselmis sp.

Methods: In the current study, Box-Behnken Design was used to model the effect of $\mathrm{NaNO}_{3}, \mathrm{NaH}_{2} \mathrm{PO}_{4}$, metals and vitamins in the F/2 medium on the growth, total chlorophylls, carotenoids and starch contents. The total chlorophylls content was quantified by spectrophotometry. The FT-IR spectroscopy was used to estimate the biochemical compositions of Tetraselmis sp. grown under both optimized medium culture for starch production and standard culture medium.

Results: Finalized $\mathrm{NaNO}_{3}(1.76 \mathrm{mM}), \mathrm{NaH}_{2} \mathrm{PO}_{4}(0.018 \mathrm{mM})$, metals $\left(1500 \mu \mathrm{L} . \mathrm{L}^{-1}\right)$ and vitamins $\left(312.5 \mu \mathrm{L} . \mathrm{L}^{-1}\right)$ concentrations, generated an increase in biomass concentration up to $5.72 \mathrm{~g} . \mathrm{L}^{-1}$ which contributed to an increase about 2.4-fold than that of the standard conditions of biomass productivity $\left(408.57 \mathrm{mg} . \mathrm{L}^{-1}\right.$. day $\left.{ }^{-1}\right)$. The maximum value of carotenoids content $\left(0.3 \mathrm{mg} \cdot \mathrm{g} \mathrm{DW}^{-1}\right)$ was achieved the highest level of all factors. The total chlorophylls content reached also its maximum $\left(5.18 \mathrm{mg} . \mathrm{g} \mathrm{DW}^{-1}\right)$ at high nitrate $(1.76 \mathrm{mM})$, phosphate $(0.054$ $\mathrm{mM}$ ), metals and vitamins concentrations, while the maximum starch content (42\% DW) was achieved with low nitrate and phosphate concentrations $(0.58 \mathrm{mM}$ and $0.027 \mathrm{mM})$ and with metals and vitamins limitations. Thus, the nitrogen, phosphorus, metals and vitamins limitations led to divert the metabolism for the starch biosynthesis.
\end{abstract}

Conclusions: The high biomass concentration productivity and starch production make Tetraselmis sp. strain a good candidate for biotechnological applications.

Keywords: Microalgae, Tetraselmis sp., Starch, Biomass, Bioactive compounds, Box-Behnken Design

\section{Background}

The rising crude oil prices, scarcity of fossil fuels, increasing environmental pollution due to $\mathrm{CO}_{2}$ and $\mathrm{NO}_{\mathrm{x}}$ emissions and increasing energy demand have led to look for renewable energy sources such as bioethanol, biodiesel and biohydrogen [1]. In this context, microalgae were considered as one of the important sources of biofuels enjoying the advantage of accumulation of lipids $(20-50 \%$ DW) and other compounds

\footnotetext{
* Correspondence: slim.abdelkafi@enis.tn

${ }^{1}$ Unité de Biotechnologie des Algues, Biological Engineering Department,

National School of Engineers of Sfax, University of Sfax, Sfax, Tunisia

Full list of author information is available at the end of the article
}

such as carbohydrates, pigments, proteins and antioxidants. Microalgae provide carbohydrates (exopolysaccharides, cell wall polysaccharides and starch) which can be used for fermentation by yeast, bacteria or fungi. For instance, Tetraselmis sp. has been suggested as a good candidate for bioethanol production owing to its high biomass and starch production [2, 3]. Nutrients disponibility in microalgal culture can regulate their growth and biochemical composition [4]. However, biomass and macromolecules (pigments and starch) production depends not only on primary nutrients (nitrogen and phosphorus) but also on metals (iron, zinc, copper, manganese, molybdenum, cobalt), some ions such as $\mathrm{Cl}^{-}, \mathrm{Ca}^{2+}, \mathrm{Na}^{2+}, \mathrm{SO}_{4}^{2-}$ and vitamins. These 
micronutrients are needed for electron transport in photosynthesis and cellular respiration, sulphate and nitrate reductions [5]. Furthermore, nutrients limitation essentially phosphorus (P) and nitrogen $(\mathrm{N})$ reduces cells growth and protein synthesis and increases starch or lipid production [4]. For example, T. subcordiformis was revealed as a great starch producing green microalga under light limitation $\left(50 \mu \mathrm{mol} \cdot \mathrm{m}^{-2} \cdot \mathrm{s}^{-1}\right)$ and nitrogen deprivation [2]. In addition, the limitation of macroelements such as nitrogen, phosphorus and sulphide can also induce starch accumulation [5-7]. Recently, Markou et al. [8] have reported that phosphorus limitation leads to the accumulation of carbohydrates and lipids. In the current study, the green microalga Tetraselmis sp. isolated from Tunisian seawater, was investigated to produce biomass, chlorophylls, carotenoids and starch. No special attention has been given yet to optimize the photoautotrophic culture of this strain for biomass, production and metabolites biosynthesis using the Response Surface Methodology (RSM). The photosynthetic performance of Tetraselmis sp. evaluated by total chlorophylls biosynthesis, was simultaneously optimized with the starch content. Therefore, the improvement of cultivation factors can reduce the cost of microalgae culture by reducing their nutrients consumption and maximizing their biomass and starch productions. Box-Behnken Design (BBD) is a useful methodology for testing the effects of the important nutritional components as their interactions would maximize cell growth, and metabolites synthesis by Tetraselmis sp. under photoautotrophic cultivation. Thus, the relationship of these products was studied under different conditions.

\section{Methods}

\section{Strain and culture conditions}

The green microalga, Tetraselmis sp. $\left(\mathrm{V}_{2}\right)$, was isolated from the Gulf of Gabes (Mediterranean Sea) along the coast of Sidi Mansour (Tunisia) using different cell isolation techniques. It was identified relying on its morphological and phylogenetic analysis (23S rDNA). Microscopic observation showed a motile, bilaterally symmetrical cells of $7-20 \mu \mathrm{m}$ in bredth, $10-25 \mu \mathrm{m}$ in length and $6.5-18 \mu \mathrm{m}$ in thickness [9]. It was characterized by their chloroplasts dorsoventrally lobed, yellow-green color and usually with pyrenoid containing many starch grains [9]. Tetraselmis sp. was cultivated at $25 \pm 1{ }^{\circ} \mathrm{C}$ under continuous light conditions $\left(84 \mu \mathrm{mol} . \mathrm{m}^{-2} . \mathrm{s}^{-1}\right)$ with white fluorescent lamps (Compact Fluorescent Lamp, Superlight, Tunisia) and at $\mathrm{pH}$ 7. Experimental cultures $(150 \mathrm{~mL})$ were inoculated with $10 \%$ of mother culture and incubated for 15 days. The microalgae was cultivated in natural seawater with the following $\mathrm{F} / 2$ nutrients (per litre) [10]: $1 \mathrm{~mL}$ $\mathrm{NaNO}_{3}\left(75\right.$ g.L $\left.\mathrm{L}^{-1}\right), 1 \mathrm{~mL} \mathrm{NaH} \mathrm{PO}_{4}\left(5\right.$ g.L $\left.{ }^{-1}\right), 1 \mathrm{~mL}$ trace metal solution and $0.5 \mathrm{~mL}$ vitamins solution. Trace metal solution was prepared in pure water containing (per liter): 3.15 g $\mathrm{FeCl}_{3}, 6 \mathrm{H}_{2} \mathrm{O} ; 4.36$ g $\mathrm{Na}_{2} \mathrm{EDTA}, 2 \mathrm{H}_{2} \mathrm{O} ; 1 \mathrm{~mL}$ $\mathrm{CuSO}_{4}, 5 \mathrm{H}_{2} \mathrm{O} \quad\left(9.8 \quad\right.$ g. $\left.\mathrm{L}^{-1}\right) ; 1 \quad \mathrm{~mL} \quad \mathrm{Na}_{2} \mathrm{MoO}_{4}, 2 \mathrm{H}_{2} \mathrm{O}$ (6.3 g.. $\left.\mathrm{L}^{-1}\right) ; 1 \mathrm{~mL} \quad \mathrm{ZnSO}_{4}, 7 \mathrm{H}_{2} \mathrm{O} \quad\left(22\right.$ g.L $\left.\mathrm{L}^{-1}\right) ; 1 \mathrm{~mL}$ $\mathrm{CoCl}_{2}, 6 \mathrm{H}_{2} \mathrm{O}\left(10\right.$ g.L $\left.\mathrm{L}^{-1}\right) ; 1 \mathrm{~mL} \mathrm{MnCl}_{2}, 4 \mathrm{H}_{2} \mathrm{O}\left(180\right.$ g.L $\left.\mathrm{L}^{-1}\right)$. The vitamin solution was prepared in pure water containing (per liter): $200 \mathrm{mg}$ thiamine $\mathrm{HCl}$ (vitamin $\mathrm{B} 1$ ), $1 \mathrm{~mL}$ biotin (vitamin $\mathrm{H})\left(1 \mathrm{~g} . \mathrm{L}^{-1}\right)$ and $1 \mathrm{~mL}$ cyanocobalamin (vitamin B12) (1 g. $\left.\mathrm{L}^{-1}\right)$. In optimization experiments, the algal cells were cultivated at three levels of four F/2 nutrients. Extracellular concentrations of $\mathrm{NaNO}_{3}$ and $\mathrm{NaH}_{2} \mathrm{PO}_{4}$ are shown in Table 1. Extracellular concentrations of metals and vitamin solution components at three levels $(-1,0,+1)$ are displayed in Table 2.

\section{Growth measurement}

The microalgae growth was determined by estimating cells concentration. After cultivation, cells were harvested by centrifugation at $5000 \times \mathrm{g}$ for $10 \mathrm{~min}$ at the late log phase. Pellets were dried at $105{ }^{\circ} \mathrm{C}$ until their weight became constant (DW).

\section{Pigments and starch contents determination}

To quantify pigments, $1 \mathrm{~mL}$ of culture was centrifuged at $5000 \times \mathrm{g}$ for $10 \mathrm{~min}$. The pellet was suspended in $1 \mathrm{~mL}$ ethanol and sonicated at $65{ }^{\circ} \mathrm{C}$ for $30 \mathrm{~min}$. After sonication, the solution was centrifuged at $5000 \times \mathrm{g}$ for 5 min and $A_{666}, A_{653}$, and $A_{470}$ were measured to quantify pigments using the equations (1), (2), (3) and (4) as described previously [11, 12];

$$
\text { [Chlorophyll a] }\left(\mathrm{mg} . \mathrm{L}^{-1}\right)=15.65 \times A_{666}-7.340 \times A_{653}
$$

$\left[\right.$ Chlorophyll b] $\left(\mathrm{mg}_{\mathrm{L}} \mathrm{L}^{-1}\right)=27.05 \times A_{653}-11.21 \times A_{666}$

$[$ Total Chlorophylls $]\left(\right.$ mg. $\left.\mathrm{L}^{-1}\right)=[$ Chlorophyll, $\mathrm{a}]+[$ Chlorophyll , b $]$

Table 1 Variables and experimental levels for F/2 medium culture optimization

\begin{tabular}{lllll}
\hline Factors & Symbol & & Levels & \\
\cline { 3 - 5 } & & -1 & 0 & +1 \\
\hline $\mathrm{NaNO}_{3}(\mathrm{mM})$ & $x_{1}$ & 0.58 & 1.17 & 1.76 \\
$\mathrm{NaH}_{2} \mathrm{PO}_{4}(\mathrm{mM})$ & $x_{2}$ & 0.018 & 0.036 & 0.054 \\
Trace metals $\left(\mu \mathrm{L}^{-} \mathrm{L}^{-1}\right)$ & $x_{3}$ & 500 & 1000 & 1500 \\
Vitamins $\left(\mu \mathrm{L} . \mathrm{L}^{-1}\right)$ & $x_{4}$ & 250 & 375 & 500 \\
\hline
\end{tabular}


Table 2 Extracellular metals and vitamins concentrations

\begin{tabular}{|c|c|c|c|}
\hline Coded Levels & -1 & 0 & +1 \\
\hline \multicolumn{4}{|l|}{ Extracellular metals concentration } \\
\hline $\mathrm{FeCl}_{3}, 6 \mathrm{H}_{2} \mathrm{O}(\mathrm{M})$ & $0.510^{-5}$ & $110^{-5}$ & $1.510^{-5}$ \\
\hline $\mathrm{Na}_{2} \mathrm{EDTA}, 2 \mathrm{H}_{2} \mathrm{O}(\mathrm{M})$ & $0.510^{-5}$ & $110^{-5}$ & $1.510^{-5}$ \\
\hline $\mathrm{CuSO}_{4}, 5 \mathrm{H}_{2} \mathrm{O}(\mathrm{M})$ & $210^{-8}$ & $410^{-8}$ & $610^{-8}$ \\
\hline $\mathrm{Na}_{2} \mathrm{MoO}_{4}, 2 \mathrm{H}_{2} \mathrm{O}(\mathrm{M})$ & $1.510^{-8}$ & $310^{-8}$ & $4.510^{-8}$ \\
\hline $\mathrm{ZnSO}_{4}, 7 \mathrm{H}_{2} \mathrm{O}(\mathrm{M})$ & $410^{-8}$ & $810^{-8}$ & $1210^{-8}$ \\
\hline $\mathrm{CoCl}_{2}, 6 \mathrm{H}_{2} \mathrm{O}(\mathrm{M})$ & $2.510^{-8}$ & $510^{-8}$ & $7.510^{-8}$ \\
\hline $\mathrm{MnCl}_{2}, 4 \mathrm{H}_{2} \mathrm{O}(\mathrm{M})$ & $4.510^{-7}$ & $910^{-7}$ & $13.510^{-7}$ \\
\hline \multicolumn{4}{|l|}{ Extracellular vitamins concentration } \\
\hline Thiamine $\mathrm{HCl}$ (vitamin $\mathrm{B} 1$ ) (M) & $1.4810^{-7}$ & $2.2210^{-7}$ & $2.9610^{-7}$ \\
\hline Biotin (vitamin H) (M) & $1.02510^{-9}$ & $1.537510^{-9}$ & $2.0510^{-9}$ \\
\hline Cyanocobalamin (vitamin B12) (M) & $1.84510^{-10}$ & $2.767510^{-10}$ & $3.6910^{-10}$ \\
\hline
\end{tabular}

$$
\begin{aligned}
\text { [Carotenoids }]\left(\mathrm{mg}_{\mathrm{L}} \mathrm{L}^{-1}\right)= & \left(1000 \times A_{470}-2.860\right. \\
& \times[\text { Chlorophyll a }]-85.9 \\
& \times[\text { Chlorophyll b] }) / 245
\end{aligned}
$$

Starch content in pellet was determined as described by Hirst et al. [13] and Xiao et al. [14] using the equation (5):

$$
\text { Starch content }\left(\mathrm{g} . \mathrm{L}^{-1}\right)=\frac{A_{600}}{2.294}
$$

\section{Experimental design and data analysis}

The effects of F/2 medium components on cells growth, pigments and starch productions by Tetraselmis sp. were evaluated and analyzed by Box-Behnken methodology [15].

The experiment design contained 27 trials (Table 3). Table 1 shows the four independent variables which are extracellular $\mathrm{NaNO}_{3}$ concentration $\left(x_{1}\right)$, extracellular $\mathrm{NaH}_{2} \mathrm{PO}_{4}$ concentration $\left(x_{2}\right)$, the metal solution initial volume $\left(x_{3}\right)$ and the vitamin solution initial volume $\left(x_{4}\right)$. These factors were studied at three levels, low (-1), medium (0) and high (+1).

The biomass concentration $\left(Y_{1}\right)$, total chlorophylls $\left(Y_{2}\right)$, carotenoids $\left(Y_{3}\right)$ and starch $\left(Y_{4}\right)$ contents were analyzed as asked responses of the experiments design.

Experimental data were fitted with a second order polynomial model (Eq. 6):

$$
\hat{Y}=\beta_{0}+\sum \beta_{\mathrm{i}} x_{\mathrm{i}}+\sum \beta_{\mathrm{ii}} x_{\mathrm{i}}^{2}+\sum \beta_{\mathrm{ij}} x_{\mathrm{i}} x_{\mathrm{j}}
$$

Where $\hat{Y}$ : response variable; $\beta_{0}$ : constant coefficient; $x_{\mathrm{i}}$ and $x_{\mathrm{j}}$ : uncoded variables ranging between the minimum and the maximum concentrations of the different factors; $\beta_{\mathrm{i}}, \beta_{\mathrm{ii}}$ and $\beta_{\mathrm{ij}}$ : coefficients for the linear, quadratic, and interaction effects, respectively.

After Tetraselmis sp. cultivation under different nutritional conditions, the statistical analysis of BoxBehnken Design of experimental results was carried out using STATISTICA software 8.0 (Stat Soft. Inc 2008).

The RSM is an efficient statistical tool to investigate the factors effect and interactions with a minimum number of experiments [16, 17]. Thus, to optimize the biomass, total chlorophylls, carotenoids and starch production $\left(Y_{1}, Y_{2}, Y_{3}, Y_{4}\right)$ by Tetraselmis sp., a total of 27 experiments were performed in this study (Table 3 ). Accordingly, $P$-values were carried out for regression analysis and to evaluate the significance of factors' effects of the first $\left(x_{1}, x_{2}, x_{3}, x_{4}\right)$ and the second $\left(x_{1}^{2}, x_{2}^{2}, x_{3}^{2}, x_{4}^{2}\right)$ order polynomials, and their interactions $\left(x_{1} x_{2}, x_{1} x_{3}, x_{1} x_{4}, x_{2} x_{3}, x_{2} x_{4}\right.$, $\left.x_{3} x_{4}\right)$.

The optimum responses were obtained with the "Response Desirability Profiling" tool of STATISTICA Software.

\section{FT-IR spectroscopy}

The absorption spectra of the samples were obtained using FT-IR spectroscopy (Agilent Technologies Spectrophotometer, Cory 630 FT-IR). The dried cells obtained from $5 \mathrm{~mL}$ of culture were pulverized to powder and pressed into tablet.

Spectrum software was employed to process the FT-IR spectra. The transmittance spectra were measured between 600 and $4000 \mathrm{~cm}^{-1}$ using 10 scans and $4 \mathrm{~cm}^{-1}$ resolution. 
Table 3 Experimental results of Box-Behnken design

\begin{tabular}{|c|c|c|c|c|c|c|c|c|}
\hline \multirow{2}{*}{$\begin{array}{l}\text { Run } \\
N^{0}\end{array}$} & \multicolumn{4}{|l|}{ Factors } & \multicolumn{4}{|c|}{ Responses } \\
\hline & $\mathrm{NaNO}_{3}(\mathrm{mM})$ & $\mathrm{NaH}_{2} \mathrm{PO}_{4}(\mathrm{mM})$ & Metals $\left(\mu \mathrm{L} . \mathrm{L}^{-1}\right)$ & Vitamins $\left(\mu \mathrm{L} . \mathrm{L}^{-1}\right)$ & $\begin{array}{l}\text { Biomass } \\
\left(\mathrm{g} . \mathrm{L}^{-1}\right)\end{array}$ & $\begin{array}{l}\text { Total chlorophylls content } \\
\left(\mathrm{mg} . \mathrm{g} \mathrm{DW} \mathrm{W}^{-1}\right)\end{array}$ & $\begin{array}{l}\text { Carotenoids content } \\
(\text { mg.g DW } \\
\text {-1) }\end{array}$ & $\begin{array}{l}\text { Starch content } \\
\left(\text { g.g DW } W^{-1}\right)\end{array}$ \\
\hline 1 & 0.58 & 0.018 & 1000 & 375 & 2.2 & 0.72 & 0.13 & 0.38 \\
\hline 2 & 1.76 & 0.018 & 1000 & 375 & 3.28 & 2.5 & 0.08 & 0.12 \\
\hline 3 & 0.58 & 0.054 & 1000 & 375 & 1.19 & 3.7 & 0.2 & 0.25 \\
\hline 4 & 1.76 & 0.054 & 1000 & 375 & 1.7 & 4.62 & 0.28 & 0.3 \\
\hline 5 & 1.17 & 0.036 & 500 & 250 & 3.37 & 2.04 & 0.06 & 0.38 \\
\hline 6 & 1.17 & 0.036 & 1500 & 250 & 4.57 & 1.15 & 0.12 & 0.26 \\
\hline 7 & 1.17 & 0.036 & 500 & 500 & 3.14 & 3.32 & 0.15 & 0.32 \\
\hline 8 & 1.17 & 0.036 & 1500 & 500 & 2.15 & 3.69 & 0.16 & 0.32 \\
\hline 9 & 1.17 & 0.036 & 1000 & 375 & 2.6 & 3.59 & 0.17 & 0.32 \\
\hline 10 & 0.58 & 0.036 & 1000 & 250 & 1.95 & 1.41 & 0.17 & 0.42 \\
\hline 11 & 1.76 & 0.036 & 1000 & 250 & 2.91 & 2.5 & 0.18 & 0.23 \\
\hline 12 & 0.58 & 0.036 & 1000 & 500 & 1.77 & 2.5 & 0.24 & 0.29 \\
\hline 13 & 1.76 & 0.036 & 1000 & 500 & 2.1 & 4.5 & 0.23 & 0.33 \\
\hline 14 & 1.17 & 0.018 & 500 & 375 & 3.39 & 1.7 & 0.09 & 0.29 \\
\hline 15 & 1.17 & 0.054 & 500 & 375 & 2.61 & 3.48 & 0.1 & 0.33 \\
\hline 16 & 1.17 & 0.018 & 1500 & 375 & 4.8 & 1.3 & 0.05 & 0.36 \\
\hline 17 & 1.17 & 0.054 & 1500 & 375 & 1.72 & 3.5 & 0.26 & 0.3 \\
\hline 18 & 1.17 & 0.036 & 1000 & 375 & 2.37 & 3.71 & 0.17 & 0.33 \\
\hline 19 & 0.58 & 0.036 & 500 & 375 & 1.94 & 2.3 & 0.16 & 0.37 \\
\hline 20 & 1.76 & 0.036 & 500 & 375 & 1.62 & 3.7 & 0.21 & 0.31 \\
\hline 21 & 0.58 & 0.036 & 1500 & 375 & 1.85 & 2 & 0.18 & 0.33 \\
\hline 22 & 1.76 & 0.036 & 1500 & 375 & 2.55 & 3.61 & 0.2 & 0.25 \\
\hline 23 & 1.17 & 0.018 & 1000 & 250 & 5.2 & 0.8 & 0.04 & 0.28 \\
\hline 24 & 1.17 & 0.054 & 1000 & 250 & 2.1 & 3.38 & 0.19 & 0.38 \\
\hline 25 & 1.17 & 0.018 & 1000 & 500 & 1.99 & 2.42 & 0.16 & 0.32 \\
\hline 26 & 1.17 & 0.054 & 1000 & 500 & 2.2 & 4.92 & 0.23 & 0.28 \\
\hline 27 & 1.17 & 0.036 & 1000 & 375 & 2.15 & 3.72 & 0.19 & 0.37 \\
\hline
\end{tabular}

\section{Results}

Optimization of $\mathrm{F} / 2$ medium components for biomass, total chlorophylls, carotenoids and starch productions by Tetraselmis sp. strain $\mathrm{V}_{2}$

Combined effects of modified-F/2 medium components on Tetraselmis sp. growth

Using the multiple regression analysis, the growth response $\left(Y_{1}\right)$ second-order equation was estimated as below to explain the Tetraselmis sp. biomass production (Eq. 7):

$$
\begin{aligned}
\hat{Y}_{1}= & 7.52-1.86 x_{1}{ }^{2}-160.45 x_{2} \\
& +1.7310^{-6} x_{3}{ }^{2}-2.610^{-2} x_{4}-6.410^{-2} x_{2} x_{3} \\
& +0.36 x_{2} x_{4}-8.8010^{-6} x_{3} x_{4}(P \text {-value }<0.05)
\end{aligned}
$$

The analysis of variance (ANOVA) was applied to check the significance of the second-order polynomial equation (Eq. 7) by fitting the experimental data shown in Table 4. The $P$-values were used to test the variables significance. As seen in Table 4, the determination coefficient $\left(R^{2}=0.94\right)$ highlighted the significance of the model and the lack of fit value is not significant $(P$-value $=0.29>0.05)$.

The lower $P$-values correspond to the high significance of the variables. In this study, $P$-values for $x_{1}^{2}, x_{2}, x_{3}^{2}, x_{4}$, $x_{2} x_{3}, x_{2} x_{4}$ and $x_{3} x_{4}$ are less than 0.05 , which explains the significance of model terms.

This indicates the strong effect of all of $F / 2$ nutrients on Tetraselmis sp. strain $\mathrm{V}_{2}$ growth. In addition, the negative regression coefficient of $\mathrm{NaH}_{2} \mathrm{PO}_{4}\left(x_{2}\right)$ and vitamins $\left(x_{4}\right)$ suggested an antagonist effect of these two components on biomass production.

Figure 1 shows the 2D (contour plots) and 3D response curves allowing us to analyze the interaction of 
Table 4 Analysis of variance of the model for biomass production

\begin{tabular}{llllll}
\hline Source & Sum of squares & $\mathrm{df}$ & Mean square & $F$ value & $P$ value \\
\hline$x_{1}$ & 0.88 & 1 & 0.88 & 17.49 & 0.05 \\
$x_{2}$ & 4.01 & 1 & 4.01 & 79.37 & $<0.05$ \\
$x_{3}$ & 0.20 & 1 & 0.20 & 4.05 & 0.18 \\
$x_{4}$ & 3.79 & 1 & 3.79 & 74.98 & $<0.05$ \\
$x_{1} x_{2}$ & 0.08 & 1 & 0.08 & 1.60 & 0.33 \\
$x_{1} x_{3}$ & 0.26 & 1 & 0.26 & 5.13 & 0.15 \\
$x_{1} x_{4}$ & 0.09 & 1 & 0.09 & 1.95 & 0.29 \\
$x_{2} x_{3}$ & 1.32 & 1 & 1.32 & 26.11 & $<0.05$ \\
$x_{2} x_{4}$ & 2.73 & 1 & 2.73 & 54.09 & $<0.05$ \\
$x_{3} x_{4}$ & 1.19 & 1 & 1.19 & 23.68 & $<0.05$ \\
$x_{1}^{2}$ & 2.25 & 1 & 2.25 & 44.50 & $<0.05$ \\
$x_{2}^{2}$ & 0.37 & 1 & 0.37 & 7.39 & 0.11 \\
$x_{3}^{2}$ & 0.99 & 1 & 0.99 & 19.58 & $<0.05$ \\
$x_{4}^{2}$ & 0.84 & 1 & 0.84 & 16.74 & 0.05 \\
Lack of fit & 1.42 & 10 & 0.14 & 2.81 & 0.29 \\
Pure error & 0.10 & 2 & 0.05 & & \\
Total & 25.82 & 26 & & & \\
\hline $\mathrm{R}^{2}=0.94$ & & & & &
\end{tabular}

the four factors and their optimal levels on Tetraselmis sp. growth. The final biomass concentration (5.72 g. $\left.\mathrm{L}^{-1}\right)$ was obtained with $1.76 \mathrm{mM}$ of $\mathrm{NaNO}_{3}, 0.018 \mathrm{mM}$ of $\mathrm{NaH}_{2} \mathrm{PO}_{4}, 1500 \mu \mathrm{L} \cdot \mathrm{L}^{-1}$ of metals solution and $312.5 \mu \mathrm{L} . \mathrm{L}^{-1}$ of vitamins solution in the culture medium.

\section{Combined effects of modified-F/2 medium components on total chlorophylls and carotenoids productions}

After identifying the significant variables for total chlorophylls $\left(Y_{2}\right)$ and carotenoids $\left(Y_{3}\right)$ production responses, the following second order response surface models were established, respectively, and illustrated in the equations (8) and (9):

$$
\begin{aligned}
\hat{Y}_{2}= & -9.48+2.78 x_{1}-0.92 x_{1}{ }^{2} \\
& +180.17 x_{2}-1378.60 x_{2}{ }^{2} \\
& +0.002 x_{3}-2.4110^{-6} x_{3}{ }^{2} \\
& +0.02 x_{4}-3.1910^{-5} x_{4}{ }^{2}-20.24 x_{1} x_{2} \\
& +3.110^{-3} x_{1} x_{4} \\
& +5.0410^{-6} x_{3} x_{4}(P \text {-value }<0.05) \\
\hat{Y}_{3}= & 0.09 x_{1}^{2}+2.66 x_{2}-72.01 x_{2}{ }^{2} \\
& +1.9510^{-4} x_{3}-1.2810^{-7} x_{3}^{2}+1.2710^{-3} x_{4} \\
& +3.06 x_{1} x_{2} \\
& +5.5610^{-3} x_{2} x_{3}(P-\text { value }<0.05) \\
&
\end{aligned}
$$

According to ANOVA results, the models corresponding to total chlorophylls (Table 5) and carotenoids
(Table 6) contents responses revealed a high determination coefficients $\left(R^{2}=0.98\right.$ and $R^{2}=0.95$, respectively) indicating the significance of the two models and the good agreement between predicted and experimental response results.

It was shown that the total chlorophylls production was influenced by all tested factors and their quadratic and interactions effects (Eq. 8). The interaction between independent factors affecting the total chlorophylls production can be estimated using the surface plot shown in Fig. 2.

In fact, increasing the extracellular $\mathrm{NaNO}_{3}$ and $\mathrm{NaH}_{2} \mathrm{PO}_{4}$ concentrations from $0.58 \mathrm{mM}$ to $1.76 \mathrm{mM}$ and from $0.018 \mathrm{mM}$ to $0.054 \mathrm{mM}$, respectively, and rising the extracellular metals $\left(1250 \mu \mathrm{L} . \mathrm{L}^{-1}\right)$ and vitamins $\left(500 \mu \mathrm{L} . \mathrm{L}^{-1}\right)$ concentrations, the total chlorophylls production reached its maximum value of 5.18 mg.g DW- ${ }^{-1}$.

The linear (except for $\mathrm{NaNO}_{3}$ ) and quadratic (except for vitamins) effects $P$-values indicated that all factors show great influence on carotenoids synthesis.

From 3D response surface plots and corresponding contour plots (Fig. 3), the maximum values of carotenoids production $\left(0.3 \mathrm{mg} . \mathrm{g} \mathrm{DW}^{-1}\right)$ response was observed at the high level (+1 level) of all the factors.

\section{Combined effects of modified- $F / 2$ medium components on starch production}

In this study, the second-order regression equation for starch production $\left(Y_{4}\right)$ was estimated through the following equation (Eq. 10):

$$
\begin{aligned}
\hat{Y}_{4}= & -0.40 x_{1}+7.30 x_{1} x_{2} \\
& +810^{-4} x_{1} x_{4}(P \text {-value }<0.05)
\end{aligned}
$$

As seen in Table 7, the determination coefficient $\left(R^{2}\right)$ of 0.88 highlighted the significance of the model. However, the linear significant effect of nitrate $\left(x_{1}\right)(P$-value $<0.05$ ) was shown to be negative.

The lower nitrate concentration coincides with the higher starch production in the tested experimental domain. A positive significant interaction $(P$-value $<0.05)$ was observed between nitrate and phosphate $\left(x_{1} x_{2}\right)$ and between nitrate and vitamins $\left(x_{1} x_{4}\right)$ (Eq. 10). The effect of phosphate, metals and vitamins was shown to be non significant for starch production $(P$-value $>0.05)$. The negative significant effect of nitrate $\left(x_{1}\right)$ seen in Eq. (10) indicated the antagonistic effect on starch content. The response observed in three dimension (3D) response surface and corresponding contour plots (2D) (Fig. 4) show the interactive effect of nutrients on starch production of Tetraselmis sp. According to the results shown in Fig. 4, the maximum of starch content value $\left(0.42\right.$ g.g DW $\left.{ }^{-1}\right)$ 
was obtained when the concentrations of $\mathrm{NaNO}_{3}$ and $\mathrm{NaH}_{2} \mathrm{PO}_{4}$ decreased from $1.76 \mathrm{mM}$ to $0.58 \mathrm{mM}$ and from $0.054 \mathrm{mM}$ to $0.027 \mathrm{mM}$, respectively, and when the volume of metal and vitamin solutions decreased from $1500 \mu \mathrm{L} . \mathrm{L}^{-1}$ to $1000 \mu \mathrm{L} . \mathrm{L}^{-1}$ and from $500 \mu \mathrm{L} . \mathrm{L}^{-1}$ to $250 \mu \mathrm{L} . \mathrm{L}^{-1}$, respectively. These results suggest that the highest starch content in Tetraselmis sp. strain $\mathrm{V}_{2}$ was obtained under nitrogen, phosphorus, metals and vitamins limitations.

\section{Carbohydrates detection by FT-IR spectroscopy}

FT-IR spectra of Tetraselmis sp. cells showed twelve distinct bands over the wavenumber ranging from
4000 to $600 \mathrm{~cm}^{-1}$ (Fig. 5). These absorption bands were attributed to specific molecular groups based on published data [18]. In this study, the spectrum of proteins which peak is at $1639 \mathrm{~cm}^{-1}$ (between 1590 and $1650 \mathrm{~cm}^{-1}$ ) corresponds to the $\mathrm{N}-\mathrm{H}$ and $\mathrm{C}=\mathrm{O}$ of amides $\mathrm{I}$, whereas the peak at $1534 \mathrm{~cm}^{-1}$ (between 1500 and $1560 \mathrm{~cm}^{-1}$ ) shows the presence of the $\mathrm{N}-\mathrm{H}$ groups and asymmetric $\mathrm{N}=\mathrm{O}$ groups of amide II. Moreover, these infra red spectra show the presence of an important peak at $3282 \mathrm{~cm}^{-1}$ allocated to the vibrations of the stretchings $\mathrm{O}-\mathrm{H}$ groups and $\mathrm{N}-\mathrm{H}$ groups of proteins.

The spectrum of the lipids was characterized by characteristic bands at $1420 \mathrm{~cm}^{-1}$ and $1380 \mathrm{~cm}^{-1}$ which

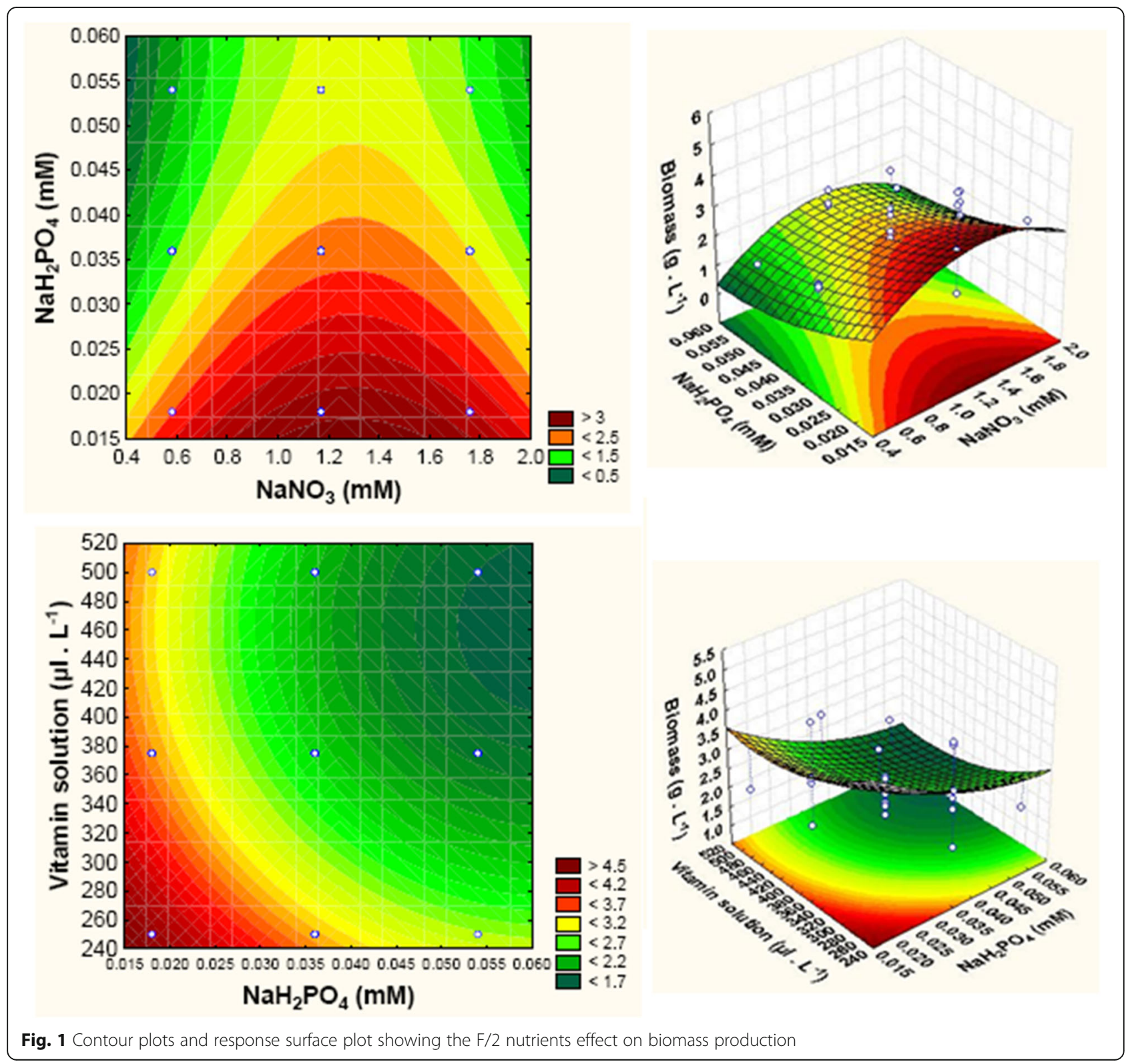


Table 5 Analysis of variance of the model for total chlorophylls production

\begin{tabular}{lcllll}
\hline Source & Sum of squares & df & Mean square & $F$ value & $P$ value \\
\hline$x_{1}$ & 6.45 & 1 & 6.45 & 1233.12 & $<0.05$ \\
$x_{2}$ & 9.77 & 1 & 9.77 & 1866.88 & $<0.05$ \\
$x_{3}$ & 0.13 & 1 & 0.13 & 26.49 & $<0.05$ \\
$x_{4}$ & 8.45 & 1 & 8.45 & 1614.72 & $<0.05$ \\
$x_{1} x_{2}$ & 0.18 & 1 & 0.18 & 35.33 & $<0.05$ \\
$x_{1} x_{3}$ & 0.01 & 1 & 0.01 & 2.10 & 0.28 \\
$x_{1} x_{4}$ & 0.20 & 1 & 0.20 & 39.55 & $<0.05$ \\
$x_{2} x_{3}$ & 0.04 & 1 & 0.04 & 8.42 & 0.10 \\
$x_{2} x_{4}$ & 0.001 & 1 & 0.001 & 0.30 & 0.63 \\
$x_{3} x_{4}$ & 0.39 & 1 & 0.39 & 75.84 & $<0.05$ \\
$x_{1}^{2}$ & 0.54 & 1 & 0.54 & 103.81 & $<0.05$ \\
$x_{2}^{2}$ & 1.06 & 1 & 1.06 & 203.32 & $<0.05$ \\
$x_{3}^{2}$ & 1.93 & 1 & 1.93 & 370.45 & $<0.05$ \\
$x_{4}^{2}$ & 1.32 & 1 & 1.32 & 252.65 & $<0.05$ \\
Lack of fit & 0.63 & 10 & 0.06 & 12.04 & 0.07 \\
Pure error & 0.01 & 2 & 0.005 & & \\
Total & 35.89 & 26 & & & \\
\hline$R^{2}=0$ & & & & & \\
\hline
\end{tabular}

$\mathrm{R}^{2}=0.98$

were due mainly to the $\mathrm{C}-\mathrm{O}-\mathrm{H}$ stretching vibrations of the carboxylic acids groups of the lipids. In addition, the peak at $1742 \mathrm{~cm}^{-1}$ was associated with lipids and fatty acids which are primarily due to $\mathrm{V}(\mathrm{C}=\mathrm{O})$ of ester groups. Finally, the successive bands at 1000, 1151 and $1227 \mathrm{~cm}^{-1}$ show the stretching of the bands of O-C groups of carboxylic acids. The carbohydrates features are characterized by two bands, at 1151 and $1000 \mathrm{~cm}^{-1}$, assigned to $\mathrm{V}(-\mathrm{O}-\mathrm{C})$ stretching vibrations of the pyranosic cycles of the polysaccharides. The nucleic acids have functional groups at $1227 \mathrm{~cm}^{-1}$ associated with $\mathrm{V}_{\text {as }}(>\mathrm{P}=\mathrm{O})$ stretching attributed to phosphorus compounds such as the phosphodiesters. The absorption bands at 1380 and $1420 \mathrm{~cm}^{-1}$ prove the presence of sulfates groups $(\mathrm{S}=\mathrm{O})$.

In this comparative study, the FT-IR analysis showed no significant changes in the qualitative biochemical composition of Tetraselmis sp. cultivated under optimized medium culture for starch production compared to the standard medium culture (factors at zero level).

\section{Discussion}

Recently, several studies, focused on research renewable sources of energy, have proved that microalgae present an important source for biofuel production $[19,20]$. Thus, the optimizations of biomass productivity, lipids and carbohydrates productions are in fact an important approach for a more economical biofuel production. The availability of nutrients such as phosphorus, nitrogen, metals, and vitamins is one of the most important factors regulating cells growth, photosynthesis and other processes in microalgae.

Nitrogen and phosphorus were the two main components that play an essential role and a significant effect on the growth of Tetraselmis sp. strain $\mathrm{V}_{2}$ (Fig. 1 and Table 4). The present study showed that the highest biomass concentration (5.72 g. $\left.\mathrm{L}^{-1}\right)$ and biomass productivity (408.57 mg. $\mathrm{L}^{-1}$. day ${ }^{-1}$ ) were obtained under high metals and nitrogen concentrations $(1.76 \mathrm{mM})$ and limited vitamins and phosphorus concentrations $(0.018 \mathrm{mM})$. Therefore, the biomass productivity increased by approximately 2.4-fold at optimized conditions compared to standard ones.

Similar results, found by Yao et al. [2], proved that with $11 \mathrm{mM}$ of $\mathrm{KNO}_{3}$ in the culture medium of Tetraselmis subcordiformis led to the higher biomass concentration (5.72 g. $\mathrm{L}^{-1}$ ) after 8 days of growth. Our findings proved that Tetraselmis cells growth was inhibited upon nitrogen starvation (Fig. 1).

Our results satisfied the hypothesis of Xin et al. [21] saying that with the increase of extracellular phosphate concentration, the biomass of microalgae decreased. In another study, the authors showed that the high concentration of phosphate decreased the growth of Chlorella [22].

In this study, Metals $\left(\mathrm{FeCl}_{3}, 6 \mathrm{H}_{2} \mathrm{O} ; \mathrm{Na}_{2}\right.$ EDTA, $2 \mathrm{H}_{2} \mathrm{O}$; $\mathrm{CuSO}_{4}, 5 \mathrm{H}_{2} \mathrm{O} ; \mathrm{Na}_{2} \mathrm{MoO}_{4}, 2 \mathrm{H}_{2} \mathrm{O} ; \mathrm{ZnSO}_{4}, 7 \mathrm{H}_{2} \mathrm{O} ; \mathrm{CoCl}_{2}, 6 \mathrm{H}_{2} \mathrm{O}$; $\mathrm{MnCl}_{2}, 4 \mathrm{H}_{2} \mathrm{O}$ ) presented a quadratic positive significant effect on cells growth. Our results showed that the highest biomass productivity (408.57 mg. $\mathrm{L}^{-1}$.day ${ }^{-1}$ ) was achieved with $0.015 \mathrm{mM}$ iron concentration (data not shown). Sun et al. [23] noted that the biomass productivity of $N$. oleobundans HK-129 increased to $292.83 \mathrm{mg} . \mathrm{L}^{-1}$.day ${ }^{-1}$ with the increase of $\mathrm{Fe}^{3+}$ concentration to $0.037 \mathrm{mM}$, which is in agreement with the present findings.

In photoautotrophic photosynthesis, iron $\left(\mathrm{Fe}^{3+}\right)$ was an essential cofactor for photosystems I and II activities. Therefore, iron affects the microalgae growth by affecting light harvesting, electron transfer, energy conversion and carbon fixation [24]. Iron limitation can also decrease the photosynthesis efficiency and biomass concentration [23].

The measurement of pigments such as total chlorophylls and carotenoids was established to analyze the effect of nutrients of $F / 2$ medium and their interactions on photosynthetic pigments production in Tetraselmis sp. (Tables 5 and 6). The highest total chlorophylls (5.18 mg.g DW $^{-1}$ ) and carotenoids (0.3 mg.g DW ${ }^{-1}$ ) contents were obtained under high extracellular concentration of all $\mathrm{F} / 2$ nutrients (Figs. 2 
Table 6 Analysis of variance of the model for carotenoids production

\begin{tabular}{llllll}
\hline Source & Sum of squares & $\mathrm{df}$ & Mean square & $F$ value & $P$ value \\
\hline$x_{1}$ & 0.0008 & 1 & 0.0008 & 6.25 & 0.12 \\
$x_{2}$ & 0.02 & 1 & 0.02 & 188.48 & $<0.05$ \\
$x_{3}$ & 0.003 & 1 & 0.003 & 25 & $<0.05$ \\
$x_{4}$ & 0.014 & 1 & 0.014 & 105.06 & $<0.05$ \\
$x_{1} x_{2}$ & 0.004 & 1 & 0.004 & 31.68 & $<0.05$ \\
$x_{1} x_{3}$ & 0.0002 & 1 & 0.0002 & 1.68 & 0.32 \\
$x_{1} x_{4}$ & 0.0001 & 1 & 0.0001 & 0.75 & 0.47 \\
$x_{2} x_{3}$ & 0.01 & 1 & 0.01 & 75.00 & $<0.05$ \\
$x_{2} x_{4}$ & 0.001 & 1 & 0.001 & 12.00 & 0.07 \\
$x_{3} x_{4}$ & 0.0006 & 1 & 0.0006 & 4.68 & 0.16 \\
$x_{1}^{2}$ & 0.005 & 1 & 0.005 & 43.34 & $<0.05$ \\
$x_{2}^{2}$ & 0.002 & 1 & 0.002 & 21.77 & $<0.05$ \\
$x_{3}^{2}$ & 0.005 & 1 & 0.005 & 41.17 & $<0.05$ \\
$x_{4}^{2}$ & 0.0003 & 1 & 0.0003 & 2.77 & 0.23 \\
Lack of fit & 0.005 & 10 & 0.0005 & 3.89 & 0.22 \\
Pure error & 0.0002 & 2 & 0.0001 & & \\
Total & 0.10 & 26 & & & \\
\hline$R^{2}=0.95$ & & & & &
\end{tabular}

$\mathrm{R}^{2}=0.95$

and 3). Just like the current study, Yao et al. [2] found that the maximal photosystem II activity $\mathrm{F}_{v} / \mathrm{F}_{m}$ increased with the increase of $\mathrm{KNO}_{3}$. Thus, chlorophylls content attained $4.9 \%$ at day 2 and at $11 \mathrm{mM}$ of $\mathrm{KNO}_{3}$, while it decreased to $1.5 \% \mathrm{DW}$ at day 8 when $\mathrm{KNO}_{3}$ was exhausted. In another study, the maximum of total chlorophylls and carotenoids productions were found in $A$. falcatus cultured in BBM medium [25] which contains a high nitrate and phosphate concentrations.
Relying on the nutrients optimization, our data showed that the maximum of starch content of $42 \%$ DW was obtained at low nitrogen, phosphorus, metals and vitamins concentrations in the culture medium of Tetraselmis sp. Therefore, the starch content increased by 1.3 -fold in the optimized F/2 medium culture compared to that at zero level (standard conditions).

The findings obtained in our research are interesting when compared to previous studies; see the findings summarized in Table 8.

A similar phenomenon has been observed in other microalgae [7, 8, 26-28]. Yao et al. [6] reported also that starch production in $T$. subcordiformis increased to a maximum of $44.1 \%$ under phosphorus limiting conditions and low initial cell densities (ICD).

It was also reported that Chlorella vulgaris produced 41\% DW of starch under nitrogen starvation [5]. It was already suggested that phosphorus deprivation induced starch accumulation (53\%) in Chlorella vulgaris Beijerinck CCALA924 [7]. As shown in Table 3, total chlorophylls content is inversely proportional to that of starch. It can be observed that at high phosphorus concentration (Runs 26 and 4) and high nitrogen concentration (Runs 13 and 22), the total chlorophylls content was high. Inversely, the Runs 1 (low $\mathrm{NaNO}_{3}$ and $\mathrm{NaH}_{2} \mathrm{PO}_{4}$ concentrations), 10 and 19 (low $\mathrm{NaNO}_{3}$ concentration) and 16 (low $\mathrm{NaH}_{2} \mathrm{PO}_{4}$ concentration) gave a high starch content, while the chlorophylls, which are compounds with high nitrogen content, were very low. The third and fourth parameters were low (between negative level $(-1)$ and zero level (0)). Similarly, Yao et al. [2] pointed out that the maximal photosystem II activity $\left(F_{v} / F_{m}\right)$ increased at high extracellular $\mathrm{KNO}_{3}$ concentration corresponding to a decrease of starch content, which is in agreement with our results and those of [29] with Chlorella vulgaris.
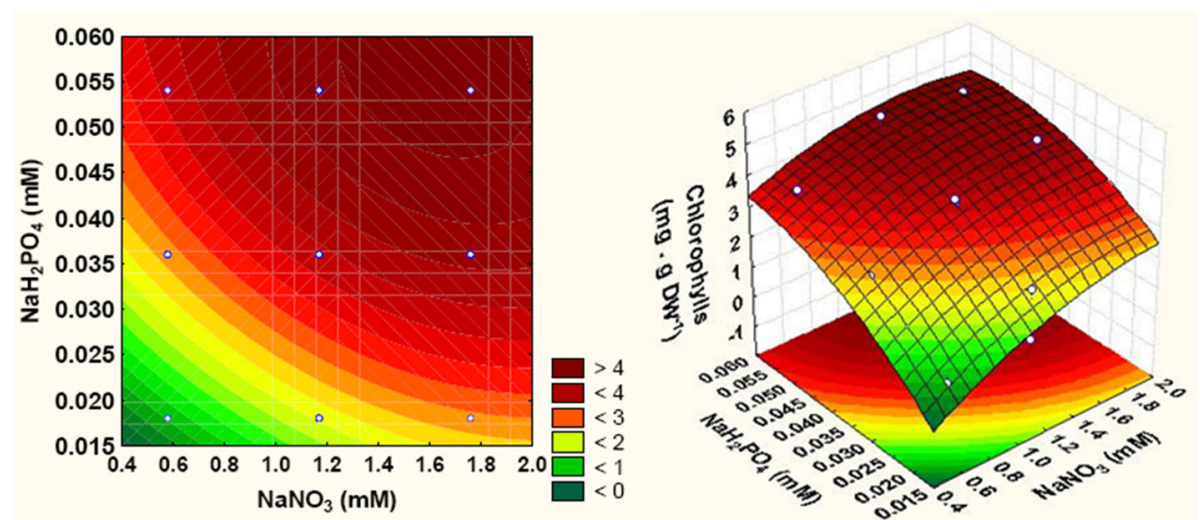

Fig. 2 Contour plots and response surface plot showing the F/2 nutrients effect on total chlorophylls production 

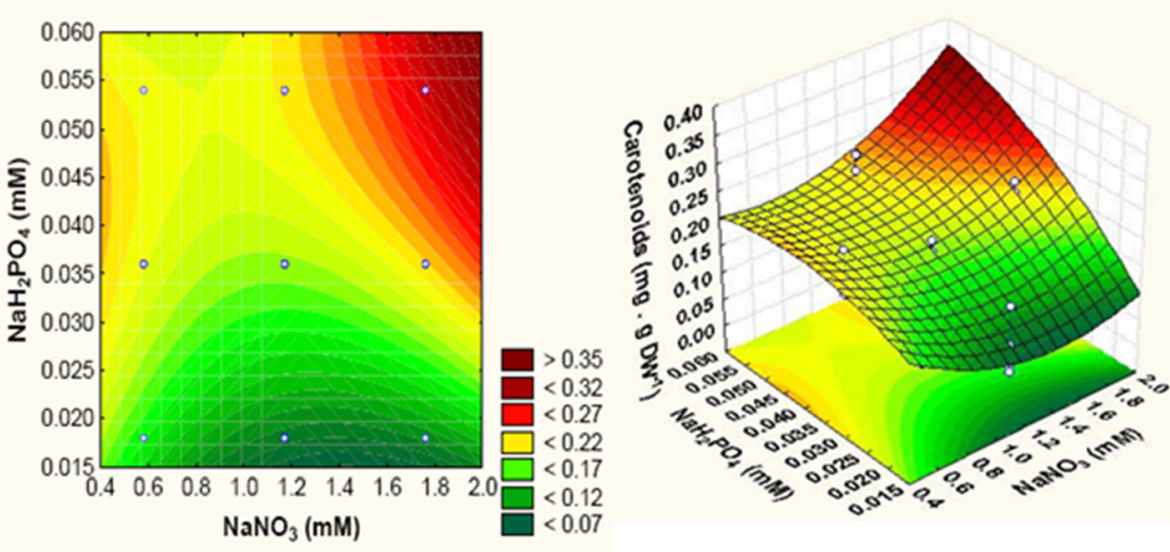

Fig. 3 Contour plots and response surface plot showing the F/2 nutrients effect on carotenoids production

The results described in our research are similar to those described by [28] suggesting that the phosphorus deprivation can lead to the deflection of metabolism from growth and photosynthesis to energy compounds such as lipids and carbohydrates. The present work clearly reveals that the decrease of initial nitrogen and phosphorus concentrations as well as metals and vitamins elements in Tetraselmis sp. strain $\mathrm{V}_{2}$ culture resulted on a maximum of starch production (Fig. 4). However, the chlorophylls content increased with the increase of nitrogen and phosphorus source in Tetraselmis sp. These results are similar to those achieved by [6]. Thus, nitrogen and phosphorus limitations caused the restriction of photosynthesis, protein and chlorophylls synthesis and the accumulation of carbohydrates and lipids $[8,25,30]$. In addition, when the nitrogen and phosphorus concentrations increased, the flow of photosynthetic carbon was diverted into chlorophylls and protein synthesis [2]. Brányiková et al. [7] assumed that the addition of cycloheximide in the medium led to the inhibition of protein synthesis and increase the starch content to below $60 \%$ DW in Chlorella vulgaris. Therefore, the nutrient stress condition such as the lack of nitrogen and phosphorus might redirect the metabolism from chlorophylls and proteins to starch accumulation. Similar results were shown with Tetraselmis subcordiformis [2], Chlamydomonas reinhardtii [31] and Dunaliella salina [32].

Furbank and Lilley [33] demonstrated that the high free phosphate concentration accumulated in the chloroplast and cytosol was toxic to the metabolism of microalgal cells, particularly to their photosynthesis [34]. In addition, it was known that starch synthesis in many plants and microalgae was carried out by the conversion of ATP and glucose-1-phosphate to pyrophosphate and ADP- glucose. This reaction was catalyzed by ADP-glucose pyrophosphorylase (AGPase) [35]. This enzyme was inhibited by free orthophosphate (Pi) and it was activated by the 3-phosphoglyceric acid (3-PGA) molecule. Therefore, the 3-PGA/Pi ratio regulated the AGPase activity [36]. The increase of the photosynthetic activity facilitated 3-PGA production with a higher 3-PGA/Pi ratio essential for the activation of AGPase and thus made the starch synthesis more efficient [6]. This

Table 7 Analysis of variance of the model for starch production

\begin{tabular}{llllll}
\hline Source & Sum of squares & df & Mean square & $F$ value & $P$ value \\
\hline$x_{1}$ & 0.021 & 1 & 0.021 & 29.76 & $<0.05$ \\
$x_{2}$ & 0.0006 & 1 & 0.0006 & 0.96 & 0.43 \\
$x_{3}$ & 0.0027 & 1 & 0.0027 & 3.85 & 0.19 \\
$x_{4}$ & 0.0006 & 1 & 0.0006 & 0.96 & 0.43 \\
$x_{1} x_{2}$ & 0.0240 & 1 & 0.0240 & 34.32 & $<0.05$ \\
$x_{1} x_{3}$ & 0.0001 & 1 & 0.0001 & 0.14 & 0.74 \\
$x_{1} x_{4}$ & 0.0132 & 1 & 0.0132 & 18.89 & $<0.05$ \\
$x_{2} x_{3}$ & 0.0025 & 1 & 0.0025 & 3.57 & 0.19 \\
$x_{2} x_{4}$ & 0.0049 & 1 & 0.0049 & 7.00 & 0.11 \\
$x_{3} x_{4}$ & 0.0036 & 1 & 0.0036 & 5.14 & 0.15 \\
$x_{1}^{2}$ & 0.005 & 1 & 0.005 & 7.24 & 0.11 \\
$x_{2}^{2}$ & 0.004 & 1 & 0.004 & 6.66 & 0.12 \\
$x_{3}^{2}$ & 0.000004 & 1 & 0.000004 & 0.005 & 0.95 \\
$x_{4}^{2}$ & 0.00002 & 1 & 0.00002 & 0.03 & 0.87 \\
Lack of Fit & 0.0095 & 10 & 0.00095 & 1.35 & 0.50 \\
Pure error & 0.0014 & 2 & 0.0007 & & \\
Total & 0.093 & 26 & & & \\
\hline$R^{2}=0.88$ & & & & &
\end{tabular}

$\mathrm{R}^{2}=0.88$ 


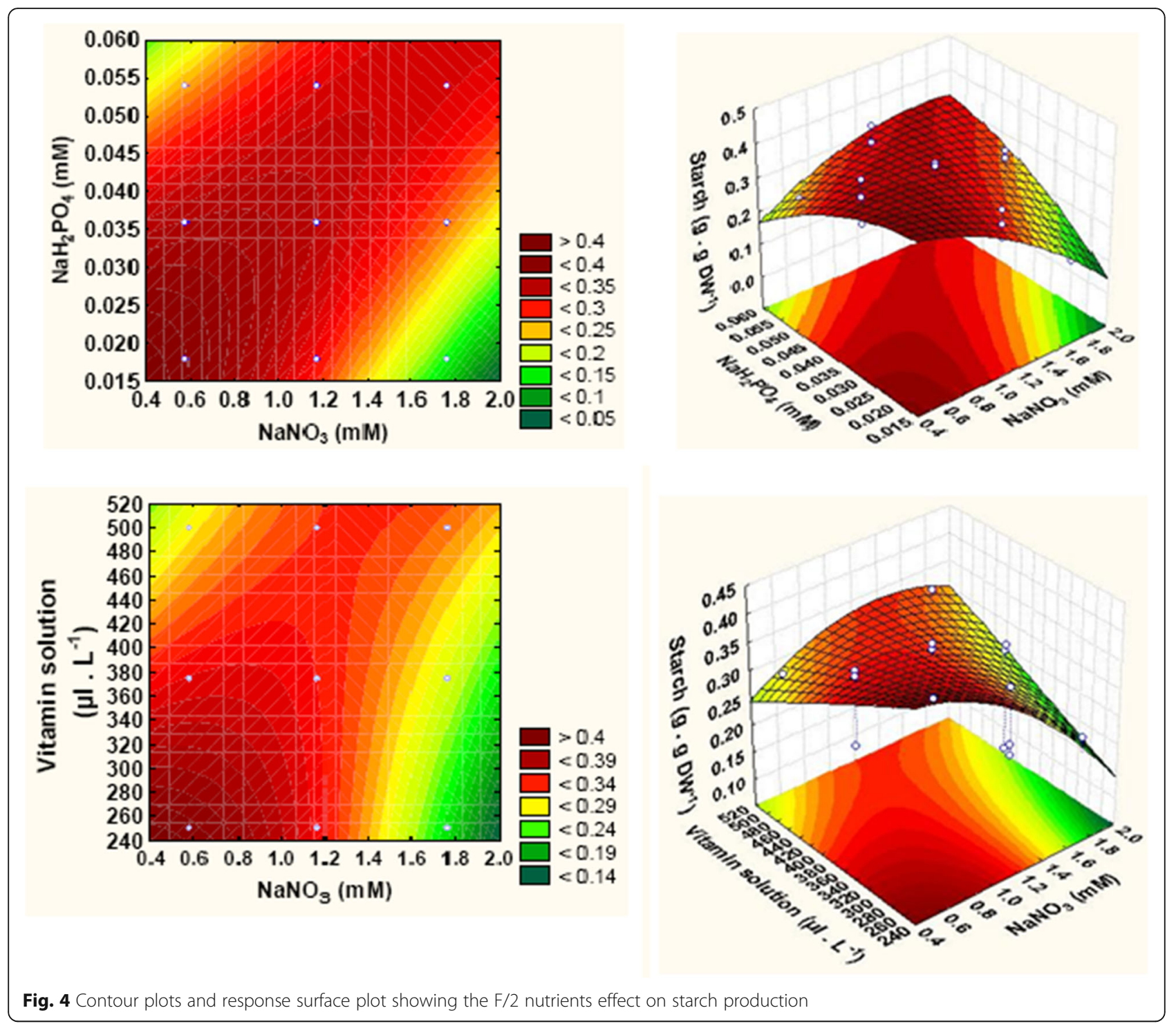

observation could explain the phenomenon of the current study showing that the lower phosphorus concentration increased the starch production. In this study, however, the metals concentration does not have a significant effect on starch synthesis in Tetraselmis sp. The maximum of starch content was obtained at zero level of metals solution volume. These findings confirm some previous results of [5], which demonstrated that irons concentration did not affect starch production in C. vulgaris. Here, the metals solution contained $\mathrm{FeCl}_{3}, 6 \mathrm{H} 2 \mathrm{O} ; \mathrm{Na}_{2}$ EDTA, $2 \mathrm{H}_{2} \mathrm{O} ; \mathrm{Na}_{2} \mathrm{MoO}_{4}, 2 \mathrm{H}_{2} \mathrm{O}$; $\mathrm{ZnSO}_{4}, 7 \mathrm{H}_{2} \mathrm{O} ; \quad \mathrm{CoCl}_{2}, 6 \mathrm{H}_{2} \mathrm{O} ; \quad \mathrm{MnCl}_{2}, 4 \mathrm{H}_{2} \mathrm{O}$ and $\mathrm{CuSO}_{4}, 5 \mathrm{H}_{2} \mathrm{O}$ which sulfur concentration was very low $\left(12.10^{-5} \mathrm{mM}\right)$ in the optimized medium culture for a maximal starch production. This result is similar to that of [2] which obtained a maximum of starch content of $62.1 \% \mathrm{DW}$ in $T$. subcordiformis at $0 \mathrm{mM}$ of $\mathrm{MgSO}_{4}$. In fact, the low sulfur concentration caused a decrease of the photosystem II activity. Therefore, the microalgal cells were exposed to culture stress conditions, hence increasing starch synthesis. In this study, Run 16 (Table 3) showed a high biomass concentration of 4.8 g. $\mathrm{L}^{-1}$ with a high biomass productivity of $343 \mathrm{mg} \cdot \mathrm{L}^{-1} \cdot$ day $^{-1}$ (data not shown) corresponding to a high starch content of $36 \%$ DW. Thus, this result is crucial to achieve a compromise between increasing cell growth and starch accumulation in Tetraselmis sp. strain $\mathrm{V}_{2}$ in order to set up a promising source for bioethanol production. Based on the FT-IR spectra analysis, the 


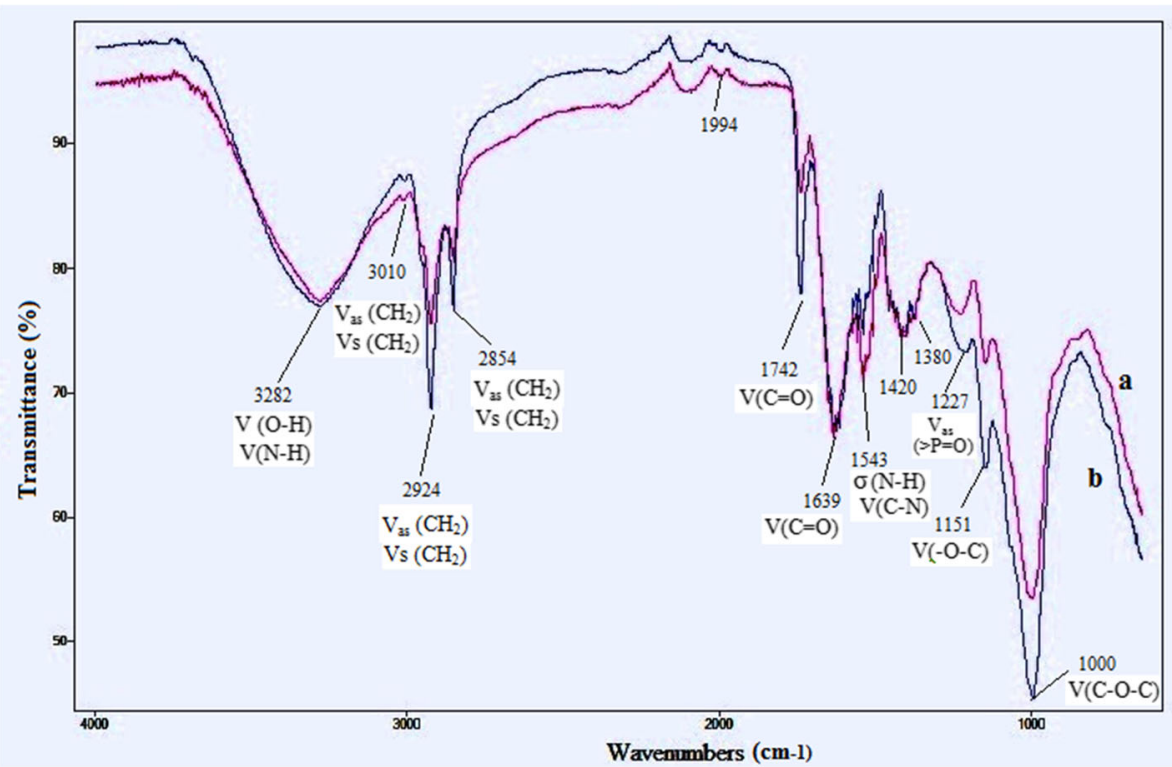

Fig. 5 FT-IR spectra for Tetraselmis sp. (a) Tetraselmis sp. cultivated under standard medium culture (factors at zero levels), (b) Tetraselmis sp. cultivated under optimized medium culture for starch production

relative carbohydrate content was calculated by measuring the ratio of the transmittance areas of the carbohydrate bands $\left(1200-950 \mathrm{~cm}^{-1}\right)$ to the amide I band $\left(1639 \mathrm{~cm}^{-1}\right)$. Thus, the carbohydrates/amide I ratio showed an increase of $16 \%$ in Tetraselmis sp. cultivated under optimized medium culture for starch production than the standard medium culture (Table 1), increasing from 7.15 to 8.29 of carbohydrates/amide I ratio. Here, the carbohydrates/amide I ratio of 8.29 for Tetraselmis sp. cultivated under optimized medium culture was higher than that obtained by $T$. subcordiformis and Chaetoceros sp. (3.07 and 2.30, respectively) [19].

As shown in this study and in previous ones, nitrogen and phosphorus limitation induced starch biosynthesis, as noted by high carbohydrates/amide I ratio [19].

\section{Conclusions}

In summary, marine microalga Tetraselmis sp. $\mathrm{V}_{2}$ reached 5.72 g.L. $\mathrm{L}^{-1}$ and $408.57 \mathrm{mg} . \mathrm{L}^{-1}$.day ${ }^{-1}$, respectively, at high metals and nitrogen concentrations and low vitamins and phosphorus ones. This was a 2.4-fold higher increase than that obtained at the standard conditions. Our study also shows that the maximum of starch content of $42 \%$ DW was obtained under nitrogen, phosphorus, metals and vitamins limitations, while the highest total chlorophylls content of $5.18 \mathrm{mg} . \mathrm{g}$ $\mathrm{DW}^{-1}$ and carotenoids content of $0.3 \mathrm{mg} \cdot \mathrm{g} \mathrm{DW}^{-1}$ were achieved at high nitrogen, phosphorus, metals and vitamins concentrations. Therefore, the isolated microalgae Tetraselmis sp. strain $\mathrm{V}_{2}$ has a good potential for biomass and starch production considering its high growth and starch content, which makes this strain a potential feedstock for bioethanol production.

Table 8 Starch production in different microalgae under different culture conditions, as reported in the literature

\begin{tabular}{llll}
\hline Microalgae & Stress conditions & Starch content (\% of DW) & References \\
\hline T. subcordiformis & $-\mathrm{P}$ (low ICD) & 44.1 & {$[6]$} \\
T. subcordiformis & $-\mathrm{P}$ (medium ICD) & 42.2 & {$[6]$} \\
T. subcordiformis & $-\mathrm{N}$ & 54.0 & 41 \\
Chlorella vulgaris & $-\mathrm{N}$ & 37 & {$[2]$} \\
Chlorella vulgaris Beijerinck CCALA924 & $-\mathrm{N}$ & 53 & {$[5]$} \\
Chlorella vulgaris Beijerinck CCALA924 & $-\mathrm{P}$ & 42.3 & {$[7]$} \\
Tetraselmis sp. & Optimized F/2 medium & & This study \\
\hline
\end{tabular}




\section{Acknowledgements}

The authors thank ISESCO and the Tunisian Ministry of higher education and scientific research for providing the funding for this research.

\section{Funding}

This work received financial support from « Ministère de l'enseignement supérieur et de la recherche scientifique ». The funding organisms had no role in study design, data collection and analysis, decision to publish, or preparation of the manuscript.

\section{Availability of data and materials}

The dataset supporting the conclusions of this article is included within the article.

\section{Authors' contribution}

$\mathrm{MD}, \mathrm{RM}, \mathrm{MB}$ and $\mathrm{FH}$ carried out characterization of microalgae and different molecules. BH carried out the statistical analysis. MD, MB, RH, IF and SA participated in the design of the study. MD, CL, PM, IF and SA conceived the study, and participated in its design and coordination and helped to draft the manuscript. All authors read and approved the final manuscript.

\section{Competing interests}

The authors declare that they have no competing interests.

\section{Consent for publication}

Not Applicable.

\section{Ethics approval and consent to participate} Not Applicable.

\section{Author details}

${ }^{1}$ Unité de Biotechnologie des Algues, Biological Engineering Department, National School of Engineers of Sfax, University of Sfax, Sfax, Tunisia. ${ }^{2}$ Université Clermont Auvergne, Université Blaise Pascal, Institut Pascal, BP 10448, F-63000 Clermont-Ferrand, France. ${ }^{3}$ CNRS, UMR 6602, IP, F-63178 Aubière, France. ${ }^{4}$ Laboratory of Plant Biotechnology, Faculty of Sciences of Sfax, University of Sfax, Sfax, Tunisia.

Received: 7 November 2016 Accepted: 24 November 2016 Published online: 20 February 2017

\section{References}

1. Nigam PS, Singh A. Production of liquid biofuels from renewable resources. Prog Energy Combust Sci. 2011;37:52-68.

2. Yao C, Ai J, Cao X, Xue S, Zhang W. Enhancing starch production of a marine green microalga Tetraselmis subcordiformis through nutrient limitation. Bioresour Technol. 2012;118:438-44.

3. Mohamed MS, Tan JS, Mohamad R, Mokhtar MN, and Ariff AB. Comparative analyses of response surface methodology and artificial neural network on medium optimization for Tetraselmis sp. FTC209 grown under mixotrophic condition. The Scientific World Journal. 2013; doi.org/10.1155/2013/948940.

4. Rasdi NW, Qin JG. Effect of N:P ratio on growth and chemical composition of Nannochloropsis oculata and Tisochrysis lutea. J Appl Phycol. 2015;27: 2221-230.

5. Dragone G, Fernandes BD, Abreu AP, Vicente AA, Teixeira JA. Nutrient limitation as a strategy for increasing starch accumulation in microalgae. Appl Energy. 2011;88:3331-5.

6. Yao CH, Ai JN, Cao XP, Xue S. Characterization of cell growth and starch production in the marine green microalga Tetraselmis subcordiformis under extracellular phosphorus-deprived and sequentially phosphorus-replete conditions. Appl Microbiol Biotechnol. 2013;97:6099-110.

7. Brányiková I, Maršálková B, Doucha J, Brányik T, Bišová K, Zachleder V, Vítová M. Microalgae—novel highly efficient starch producers. Biotechnol Bioeng. 2011;108:766-76.

8. Markou G, Chatzipavlidis I, Georgakakis D. Effects of phosphorus concentration and light intensity on the biomass composition of Arthrospira (Spirulina) platensis. World J Microbiol Biotechnol. 2012;28:2661-70.

9. Arora M, Anil AC, Leliaert F, Delany J, Mesbahi E. Tetraselmis indica (Chlorodendrophyceae, Chlorophyta), a new species isolated from salt pans in Goa, India. Eur J Phycol. 2013;48:61-78.
10. Guillard RRL. Culture of phytoplankton for feeding marine invertebrates. In: Smith WL, Chanley $\mathrm{MH}$, editors. Cultures of Marine Invertebrate Animals. Plenum Press; 1975. p. 29-60.

11. Lichtenthaler HK, Wellburn AR. Determination of total carotenoids and chlorophylls A and B or leaf in dissolved solvents. Biol Soc Trans. 1985;11:591-2.

12. Kumar P, Ramakritinan CM, Kumaraguru AK. Solvent extraction and spectrophotometric determination of pigments of some algal species from the shore of puthumadam, southeast coast of India. Int J Oceans Oceanography. 2010;4:29-34.

13. Hirst SE, Manners DJ, Pennies IR. The molecular structure of starch-Type polysaccharides from Haematococcus pluvialis and Tetraselmis carteriiformis. Carbohyd Res. 1972;22:5-11.

14. Xiao Z, Storms R, Tsang A. A quantitative starch-iodine method for measuring alpha-amylase and glucoamylase activities. Anal Biochem. 2006;351:146-8.

15. Box GEP, Behnken EW. Some new three level designs for the study of quantitative variables. Technometrics. 1960;2:455-75.

16. Patil PD, Gude UG, Mannarswamy A, Deng S, Cooke P, Munson-McGee S, Rhodes I, Lammers P, Nirmalakhandan N. Optimization of direct conversion of wet algae to biodiesel under supercritical methanol conditions. Bioresour Technol. 2011;102:118-22.

17. Ryu B, Kang KH, Ngo DH, Qian ZJ, Kim SK. Statistical optimization of microalgae Pavlova lutheri cultivation conditions and its fermentation conditions by yeast, Candida rugopelliculosa. Bioresour Technol. 2012:107:307-13.

18. Meng $Y$, Yao C, Xue S, Yang H. Application of Fourier transform infrared (FT-IR) spectroscopy in determination of microalgal compositions. Bioresour Technol. 2014;151:347-54.

19. Dammak M, Haase SM, Miladi R, Ben Amor F, Barkallah M, Gosset D, Pichon C, Huchzermeyer B, Fendri I, Denis M, Abdelkafi S. Enhanced lipid and biomass production by a newly isolated and identified marine microalga. Lipids Health Dis. 2016;15(1):209.

20. Chtourou H, Dahmen I, Jebali A, Karray F, Hassairi I, Abdelkafi S, Ayadi H, Sayadi S, Dhouib A. Characterization of Amphora sp., a newly isolated diatom wild strain, potentially usable for biodiesel production. Bioprocess Biosyst Eng. 2015;38:1381-92.

21. Xin L, Hong-ying $H$, Ke G, Ying-xue S. Effect of different nitrogen and phosphorus concentrations on the growth, nutrient, and lipid accumulation of a freshwater microalga Scenedesmus sp. Bioresour Technol. 2010;101:5494-500.

22. Liang K, Zhang Q, Gu M, Cong W. Effect of phosphorus on lipid accumulation in freshwater microalga Chlorella sp. J Appl Phycol. 2013;25:311-8.

23. Sun $X$, Cao Y, Xu H, Liu Y, Sun J, Qiao D, Cao Y. Effect of nitrogen starvation, light intensity and iron on triacylglyceride/carbohydrate production and fatty acid profile of Neochloris oleobundans HK-129 by a two stage process. Bioresour Technol. 2014;155:204-12.

24. Terauchi AM, et al. Trophic status of Chlamydomonas reinhardtii influences the impact of iron deficiency on photosynthesis. Photosynth Res. 2010;105:39-49.

25. George B, Pancha I, Desai C, Chokshi K, Paliwal C, Ghosh T, Mishra S. Effects of different media composition, light intensity and photoperiod on morphology and physiology of freshwater microalgae Ankistrodesmus falcatus - A potential strain for bio-fuel production. Bioresour Technol. 2014;171:367-74.

26. Dean AP, Estrada B, Nicholson JM, Sigee DC. Molecular response of Anabaena flos-aquae to differing concentrations of phosphorus: a combined Fourier transform infrared and X-ray microanalytical study. Phycol Res. 2008:56:193-201.

27. Dean AP, Nicholson JM, Sigee DC. Impact of phosphorus quota and growth phase on carbon allocation in Chlamydomonas reinhardtii: an FT-IR microspectroscopy study. Eur J Phycol. 2008;43:345-54.

28. Markou G. Alteration of the biomass composition of Arthrospira (Spirulina) platensis under various amounts of limited phosphorus. Bioresour Technol. 2012:116:533-5.

29. LV JM, Cheng LH, Xu XH, Zhang L, Chen HL. Enhanced lipid production of Chlorella vulgaris by adjustement of cultivation conditions. Bioresour Technol. 2010;101:6797-804.

30. Wykoff DD, Davies JP, Melis A, Grossman AR. The regulation of photosynthetic electron transport during nutrient deprivation in Chlamydomonas reinhardtii. Plant Physiol. 1998;117:129-39.

31. Zhang LP, Happe T, Melis A. Biochemical and morphological characterization of sulfur-deprived and $\mathrm{H} 2$-producing Chlamydomonas reinhardtii (green alga). Planta. 2002;214:552-61.

32. Cao HM, Zhang LP, Melis A. Bioenergetic and metabolic processes for the survival of sulfur-deprived Dunaliella salina (Chlorophyta). J Appl Phycol. $2001 ; 13: 25-34$. 
33. Furbank RT, Lilley RM. Effects of inorganic phosphate on the photosynthetic carbon reduction cycle in extracts from the stroma of pea chloroplasts. Biochim Biophys Acta. 1980;592:65-75.

34. Nielsen ES, Rochon T. The Influence of extremely high concentrations of inorganic $\mathrm{P}$ at varying $\mathrm{pH}$ on the growth and photosynthesis of unicellular algae. Int Revue ges Hydrobiol. 1976;61:407-15.

35. Ball SG, Morell MK. From bacterial glycogen to starch: understanding the biogenesis of the plant starch granule. Annu Rev Plant Biol. 2003;54:207-33.

36. Ball SG. Regulation of starch biosynthesis. In: Rochaix JD, GoldschmidtClermont $\mathrm{M}$, Merchant $\mathrm{S}$, editors. The molecular biology of chloroplasts and mitochondria in Chlamydomonas, Kluwer, The Netherlands; 1998, p. 549-567.

Submit your next manuscript to BioMed Central and we will help you at every step:

- We accept pre-submission inquiries

- Our selector tool helps you to find the most relevant journal

- We provide round the clock customer support

- Convenient online submission

- Thorough peer review

- Inclusion in PubMed and all major indexing services

- Maximum visibility for your research

Submit your manuscript at www.biomedcentral.com/submit
Biomed Central 